\title{
Hamster Neoplasm
}

National Cancer Institute

\section{Source}

National Cancer Institute. Hamster Neoplasm. NCI Thesaurus. Code C134988.

A neoplasm occurring in a hamster. 